\title{
Wallace M. Short, \\ Forgotten Warrior of the Farm Holiday
}

\author{
W. H. C U M B E R L A N D
}

Almost forgotten among the major participants of the Iowa "Cow War" in 1931 and the Farm Holiday strike of 1932 is Wallace M. Short, former Sioux City minister, mayor, member of the state legislature, and editor of a farm-labor paper, the Unionist and Public Forum. Short's vigorous editorials and speeches, along with his close association with Milo Reno, helped stir farmers to action.

For years, Short had been one of Iowa's colorful and controversial figures. His opposition to prohibition and the Woodbury County AntiSaloon League cost him a prestigious pulpit at First Congregational Church in Sioux City. Several years later, he astounded western Iowa conservatives by winning the mayoralty at the head of a labor ticket. $\mathrm{He}$ attracted national attention by defending the free speech rights of the Industrial Workers of the World (IWW) and by delivering, in April 1919, a daring address before a convention of "wobblies" held in the Missouri River community-which nearly resulted in his dismissal as mayor in a heated recall election. In 1921, while still mayor, he preached the funeral sermon of an Islamic packinghouse striker who had shot the son of the county sheriff and was killed in turn; and he was one of the few Iowa public officials who, during the zenith of their power, openly attacked the Ku Klux Klan, whom he described as "jackals who hunt in packs under cover of night." 1

Few could have challenged Short as Iowa's most distinguished radical during the 1920s and 1930s. Otha D. Wearin, who served in the Forty-third Iowa General Assembly with Short, found him one of the most picturesque figures in the legislature. He remembered that while Short was classified as a Republican, "he was so far left of

1 Sioux City Journal, September 14, 1923. 
left that he couldn't even see the Republican party and the party couldn't see him." 2 This was a man who had grown up on a farm near the small town of College Springs, Iowa, during the immediate post-Civil War era, who received his education from Beloit College and Yale Theological Seminary, and who served pastorates at Evansville, Wisconsin, and Kansas City, Missouri, before arriving in Sioux City in May 1910. His religious and political views owed much to the dean of congregationalism, Washington Gladden, and the father of the Progressive movement, Robert M. La Follette. ${ }^{3}$

When he was defeated in a challenge to eleventh district incumbent William Boies for the GOP congressional nomination in 1924, Short launched a journalistic career. First he became editor of a labor paper, the Union Advocate, published by "Billy" Bastian of Sioux City. When Bastian and Short disagreed over editorial policy (Short wanted a farmer-labor paper), he started his own paper, the Unionist and Public Forum, which he edited and published until 1949, when ill health forced him into grudging retirement at age 83 . Being an editor did not diminish his political ambition, for he sought a fourth term as Sioux City's mayor in 1926, managed La Follette's Progressive presidential campaign in Woodbury County in 1924, Smith W. Brookhart's senatorial primary campaign in Woodbury County in 1926, and won election to the Iowa General Assembly in 1930. In 1934 Short was one of the organizers of the Farmer-Labor party of Iowa and ran three times for governor. In 1936 he supported William Lemke, Union party candidate for president. He was indeed a political maverick who constantly searched for a better social and economic order than the traditional parties seemed able to provide.

Short's editorial rhetoric was populist as he railed against those who in his view plundered the people-the international bankers and financiers, the corrupt politicians who represented special interests, and newspapers like the Des Moines Register, which he charged with having sold out to the big-money boys. The views of the former mayor expressed through the Unionist and Public Forum stirred dissent among militant farmers during the critical depression years, 1931-34. His oft-quoted motto: "This is our country. It is a place for us to be happy in; not merely a place for a few to get rich in"

2 Otha D. Wearin, Country Roads to Washington (Des Moines: WallaceHomestead, 1976), p. 23.

$3 \mathrm{~A}$ biographical account of Wallace M. Short may be found in Mary Eliza Morse Short, Just One American (n.p., 1943). Short is also listed in Who's Who in America, 1950-1951. 
reminded readers of his dedication to the common people. ${ }^{4}$ Short's connections were strong with the Farmers' Union and with the Farm Holiday Association of Milo Reno when it was founded in May 1932. $\mathrm{He}$ endorsed the program of these organizations which included cost of production, the Frazier-Lemke refinance bill (to halt foreclosures on farmers unable to meet their mortgage payments), and inflationary measures to restore farm prosperity. ${ }^{5}$ In Iowa neither the administration of Republican Dan Turner (1931-33) nor that of Democrat Clyde Herring (1933-37) met with his approval. Both governors, according to Short, had threatened the liberties of the people by calling out the National Guard to restore civil order during the "Cow War" and during the disturbances in Plymouth and Crawford counties in the spring of 1933. Governor Turner had also threatened to use the militia to break the blockade of Iowa highways during the Farm Holiday strike in August and September 1932.

Iowa's travail started in the summer of 1931 when irate farmers in several eastern counties resisted the state's mandatory tuberculosis-testing law. There were armed confrontations between farmers and veterinarians backed by deputies, compelling Governor Turner to summon the National Guard. The leading organizers of the resistance were Paul Moore, a former socialist organizer for the Iowa Farmers' Union, and Jacob Lenker, a Wilton farmer and president of the Farmers' Protective Association, an organization created for the purpose of obstructing the testing. ${ }^{6}$ The power of the state was levied against Moore and Lenker, who received three-year prison terms after being convicted of "conspiracy to violate a law." They

4 Exceedingly important in this study were issues of the Iowa Union Farmer and the Farm Holiday News and collections of papers of Milo Reno, Brainerd H. Shearer, John Shover, Grant White, and U.S. Farmers Association papers located in the Special Collections Department of The University of Iowa Libraries. Important materials at the State Historical Society in Iowa City concerning Short's background and his involvement in the Cow War and the Holiday strike include issues of the Unionist and Public Forum, the Estherville Daily News, the Union Advocate, and papers of Grant Munger and Claude $M$. McMillan. Several boxes of Short material, loaned to me by Short's daughter, Mrs. Robert Hunter of Sioux City, are now located at the Sioux City Public Museum. This material includes personal letters between Short and other family members, notably his brother William, who served as secretary and member of the executive committee of the League to Enforce Peace, 1915-1923. The letters terminate in 1921, but the collection also contains photographs, sermons, and materials related to Short's six years as mayor of Sioux City, 1918-24, and his defense of the free speech rights of the IWW.

5 Unionist and Public Forum, June 21, 1934.

6 John Shover, Cornbelt Rebellion (Urbana: University of Illinois Press, 1965). p. 31 . 
were paroled, however, after serving only 40 days by a governor who sought to avoid creating martyrs. ${ }^{7}$

Opponents of the tests argued that they were unreliable, provided jobs only for veterinarians, caused cows to abort, and enabled packers to purchase low-priced meat which they proceeded to sell to unsuspecting customers. ${ }^{8}$ The tests did not cause the cows to abort, and they did help eradicate bovine tuberculosis. Dr. D. C. Lochead of the Mayo Clinic and Dr. Arthur A. Steindler of The University of Iowa endorsed the tests. Dr. Lochead claimed that 25 percent of the tuberculosis cases in children were of the bovine type. ${ }^{9}$ On the other hand, the tests were not completely reliable and some uninfected cattle were slaughtered. Furthermore, the farmers were only partially compensated for condemned cattle, and average losses of $\$ 130$ were difficult to accept during hard times. ${ }^{10}$

Then a member of the legislature, Short openly sympathized with the militants and parroted the line of the Farmers' Union in his opposition to the testing law. A featured speaker, along with Senator Smith W. Brookhart, at Estherville's Fourth of July celebration in 1931, Short castigated the Iowa General Assembly, urging the voters to clean out "the human reactors from the Iowa House and Senate." Poor representatives, he told his audience in the Estherville auditorium, were more dangerous than "bovine reactors." $11 \mathrm{He}$ wished, however, to avoid conveying the impression that he was hostile to science. He regarded himself as a reformer, not a traditionalist, and during his tenure as mayor of Sioux City he had advocated sanitation measures and solidly supported the State Board of Health. No one, he claimed, supported scientific research more than he, but now Short "feared the dictatorship of second-rate scientists."12 By midsummer 1931, Short found the TB "Test Tangle" to be the hottest item in Iowa politics, and he insisted that both veterinarians and government inspectors had informed him that the law so thoughtlessly rushed through the legislature "was a mistake."13

Some Iowa newspapers were critical of Short's speeches and editorials in the Unionist, which they felt stirred opposition to the TB testing law. Among them was Bastian's paper, the Union Advocate,

\footnotetext{
7 lowa Union Farmer, September 20, 1933.

8 "The Cow War," Grant White Papers in Special Collections, The University of Iowa Libraries.

9 Des Moines Register, April 2, 1941.

10 Shover, Cornbelt Rebellion, p. 29.

11 Estherville Daily News, July 6, 1931.

12 Iowa Union Farmer, September 9, 1931.

13 Ibid., June 30, 1931.
} 
which caricatured Short as "that tall and saintly gentleman" who "preferred to get involved in TB testing with men who defy the law." The Advocate noted that those who "took his advice to be martyrs" were now under sentence in the state prison. ${ }^{14}$ John Horswell, reporting for the Estherville Daily News, credited Governor Turner with preventing a revolt and ridiculed Short's scientific knowledge, charging that he had misled the farmers. Horswell chided Short for circulating copies of the Unionist and Public Forum with the caption, "For Health's sake, drink milk from TB cows."15 Short was obviously referring to Marion Syndegaard, who had won recognition as the "healthiest girl in the United States" and credited her buxom health to the quart of milk she drank each day from her father's herd-which in June 1931, had tested out tubercular. ${ }^{16}$ Short, Horswell was convinced, was sowing seeds of insurrection. "Now," he wrote, "let Wallace Short take his share of the blame . . ."17

While Short may have been on weak scientific ground and wrong in his assertion that the testing program was unnecessary, his opposition to the law went deeper. The law represented to him another unwarranted intrusion of government into the lives of individuals. He feared that such intrusions, backed up with the military power of the state, might lead to dictatorship. Furthermore, farmers whose cattle were reactors suffered disastrous economic losses. The program, he cautioned, was being administered "not for the benefit of health, but for the profit and monopoly of the few."18

By 1931, Short was already deeply involved in his support of the Farmers' Union and the policies of Milo Reno. He would soon be enmeshed in the politics of the Farm Holiday Association and the turbulent strikes of late summer 1932. The Farm Holiday Association had been organized by Milo Reno at Des Moines in early May 1932 for the purpose of creating an organized withholding action among farmers until cost of production was achieved. Farm commodities, by midsummer, had declined to one-third of their 1914 levels, with hogs bringing $\$ .03$ a pound, corn $\$ .10$ a bushel, and butterfat $\$ .18$ a pound. Short and Reno were both convinced that Hoover's agricultural program would soon reduce the farmer to peasantry.

In August 1932, Reno launched his first withholding action, in

14 Union Advocate, May 27, 1932.

15 Estherville Daily News, November 25, 1931.

16 Ibid., July 6, 1931. See also Roland White, Milo Reno (Iowa City: Printed by the Athens Press. 1941; reprinted with added notes. New York: Arno Press, 1975 ), p. 61.

17 Estherville Daily News, November 25, 1931.

18 Unionist and Public Forum, September 12, 1935. 
which he was joined by the Sioux City milk producers as well as angry and desperate grain and livestock farmers. The milk producers were striking against the J. R. Roberts Dairy Company, demanding an increase in price from $\$ 1.00$ per hundred pounds to $\$ 2.17$. The farmer was currently receiving only $\$ .02$ for a quart of milk that cost consumers \$.08. In the Unionist and Public Forum, Short led the attack upon what he regarded as the monopolistic and unfair pricing techniques of Roberts. J. R. Roberts, in turn, insisted that his company would not deal with any milk producer "who contributes to the financial support of Mr. Short or his paper."19

By mid-August virtually all shipments of farm produce into Sioux City had been halted as fifteen hundred farmers blockaded five major highways. ${ }^{20}$ Passing vehicles were stopped by bridge planks 4 " by $4^{\prime \prime}$ by $16^{\prime}$ with 30 penny spikes sticking up at strategic points across the highway. ${ }^{21}$ Some violence was inevitable; and near Sioux City, his patience exhausted, Sheriff John A. Davenport "hauled picketers to jail by the truckload." Many, however, returned to the picket lines as soon as they were released. ${ }^{22}$ Tension along the blockaded roads was so great that a Sioux City Tribune reporter wrote that "the air seems to vibrate like a fiddle string." ${ }^{23}$ Short was proud of the role that his paper played, noting that many people had informed him that "the Unionist has been the leading power back of these activities that have attracted national and international attention." 24

Although Short was not one of the organizers of the strike, he was a major publicist for the embattled farmers. He represented their grievances through the columns of the Unionist, and many of his articles were reprinted in the Iowa Union Farmer. The Unionist as a labor paper, however, reached an element not accessible to the agricultural press. Short was interviewed at the Statehouse by Arthur Holt of the Christian Century; and the Sioux City Journal and the Des Moines Register made references to Short as he spoke at Farm Holiday celebrations across Iowa. Although not officially a mem-

19 Ibid., August 4, 1932. Also tape recordings, John Shover Collection, Special Collections, The University of Iowa Libraries.

20 John Shover, "The Farm Holiday Strike," Agricultural History (October 1965), p. 199.

21 Dan Turner manuscript in the John Shover Collection, p. 9.

22 David Korgan, "Farmers Picket the Depression" (Ph.D. diss., American University, 1961$)$, p. 72 .

23 Sioux City Tribune, August 18, 1932.

24 Unionist and Public Forum, October 6, 1932. Also tape recordings, Shover Collection. 


\section{THE IOWA UNION FARMER}

"In Union There Is Strength"

\section{Farmers' “Strike" Is Now On In Iowa}

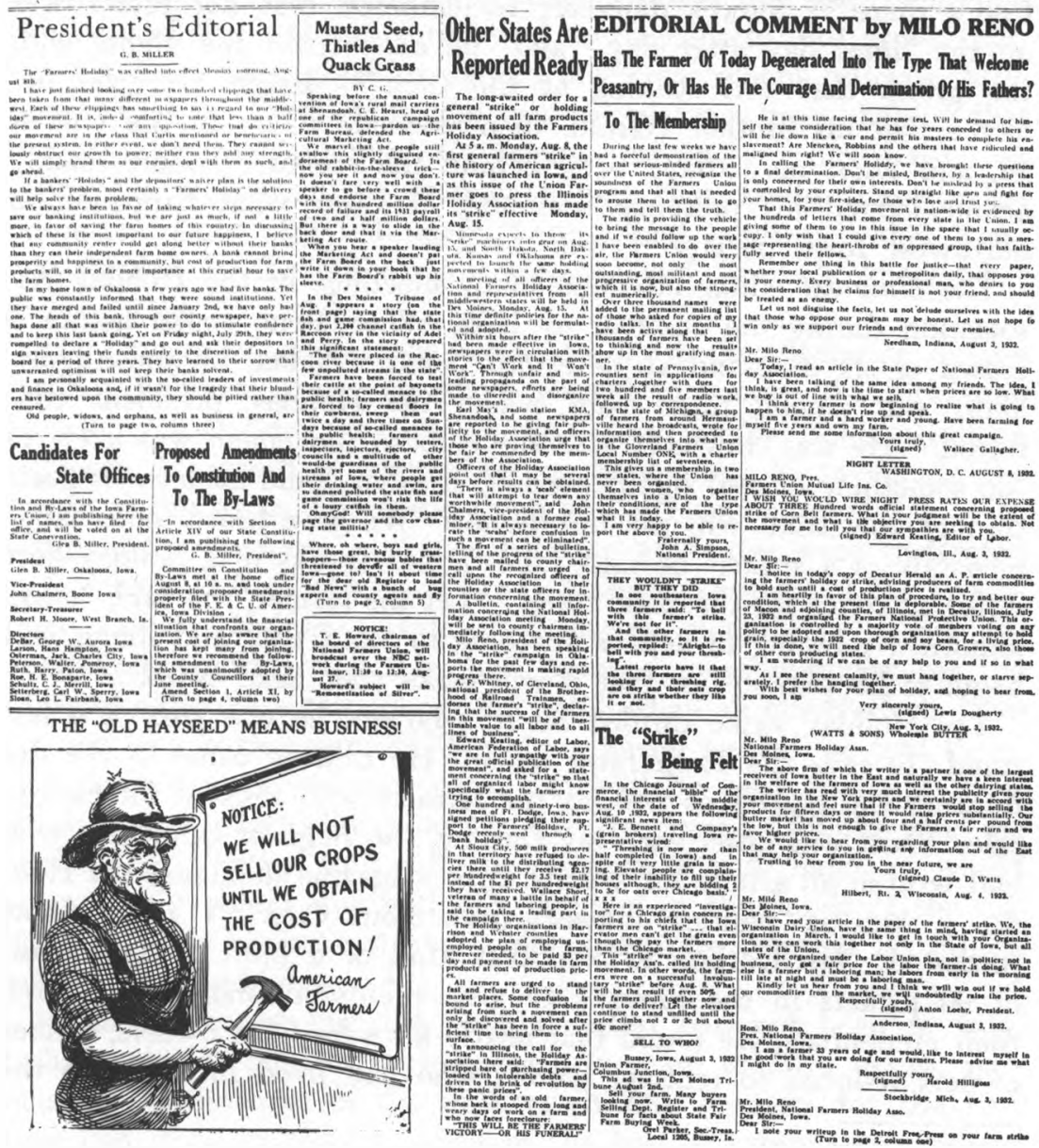

Front page of the August 10, 1932, issue of the Iowa Union Farmer. From a copy in The University of Iowa Libraries. 
ber, Short called himself the "brother-in-law" of the Iowa Farmers' Union. ${ }^{25}$ When the farmers undertook the Farm Holiday strike, Short followed them on the picket lines. Roland White, recalling the action around Sioux City, wrote that "Wallace Short was a leading figure there." 26 Short's daughter remembered that her father was on the "lines day after day," and "he even spent the nights with the group that was striking at the time." 27 Ralph Sturgeon believed that his brother Harold, then associate editor of the Unionist, and Short may "have been behind the scenes." 28 Short readily acknowledged his presence, claiming, "I know what happened in northwest Iowa because I was there." 29

The Unionist editor attended many meetings of the Holiday Association during the summer of 1932. When Reno spoke before a crowd of six thousand at Beresford, South Dakota, in mid-August, Short was among those with whom the Holiday president conferred. ${ }^{30} \mathrm{He}$ was convinced that the Holiday movement was likely to "do something of real significance." 31 If labor could achieve its goals through the strike, why not the farmer? "We have heard union labor men talk of a strike," he said; "the farmer speaks of a holiday-just different terms for the same thing." "Let the farmer," he said, "cease tomorrow morning to deliver anything in Sioux City and things will begin to happen so fast that it will make your head swim." 32

The Holiday strike thrilled Short, who felt he was part of a last stand "to save the Iowa farm home." He quickly came to the defense of the pickets as well as the farmers who resisted foreclosure sales. Short was upset with Jay Darling, the Register cartoonist, who had written an article for a New York magazine depicting the Holiday pickets as "political outcasts from Sioux City." "I want," Short protested, "Jay Darling to stop that kind of a bluff." 33 The arrest of 90 pickets in the Sioux City area prompted Short to research their credentials. He found that nearly all were farm owners, former owners reduced to renting, renters who had lived for years in the

25 Minutes of the Twenty-fourth Annual Convention of the Iowa Division of the Farmers Educational and Cooperative Union of America, September 18, 1940, p. 30. Copy in the U.S. Farmers Association Records, Special Collections, The University of Iowa Libraries.

26 White, Milo Reno, p. 75.

27 Interview with Mrs. Robert F. Hunter, September 16, 1979.

28 Interview with Mr. Ralph Sturgeon, October 5, 1979.

29 Minutes of the Seventeenth Annual Convention. p. 63.

30 Sioux City Tribune, August 16, 1932.

31 Iowa Union Farmer, July 13, 1932.

32 Ibid.

33 Minutes of the Seventeenth Annual Convention, p. 63. 
community or farm youths still living with their parents. Six were carpenters or packinghouse workers living in Sioux City who had come to assist the farmers. ${ }^{34}$ Far from being political outcasts, Short found the men represented as "fine a type of citizenship as there is in America." 35 Both Short and Reno realized that the continued blockade of the highway threatened to degenerate into armed battles between the angry farmers and law enforcement officials. Milo Reno, upset by the growing violence, called for a truce, hoping that the Midwestern Governors' Conference meeting in Sioux City on September 9, 1932 might produce a plan that would alleviate the desperate plight of the farmers. Later, Short confirmed that Reno was startled by the outbreak of violence and "scarcely knew what to do with it." 36

The governors' conference failed to meet the demands of the Holiday militants, many of whom wished to resume the picketing. Hundreds of Holiday men met at the Golden Slipper Dance Hall on Highway 141 south of Sioux City on September 13 to decide the future of the strike. Short was there as the farmers voted 2 to 1 to continue the blockade, and the antistrike advocates were castigated as "slackers." 37 Both Short and W. C. Daniel, president of the Woodbury County Holiday Association, urged moderation. Short reminded the pickets that they had "created more publicity for the cause of agriculture throughout the nation than all other efforts have secured in a dozen years." 38 "For six or seven weeks," he told them, "you have done a piece of work that will be read about by your children and grandchildren in the days to come." "Would you," he chided them, "rather stop with the program in your hands or would you rather it would stop with the program in the hands of the militia?"39 While he met with some opposition, he believed his efforts helped clear the highways. ${ }^{40}$

He also believed that the Holiday effort had not been in vain. It had achieved at least a temporary increase in farm prices, particularly in the case of the milk producers. Farmers for the first time had stood united on behalf of the cost of production, without which "there could never be equality in agriculture." Not only Iowans but people across the country were now aware that "this is

\footnotetext{
34 Iowa Union Farmer, July 13, 1932.

35 Unionist and Public Forum, May 17, 1934.

36 Iowa Union Farmer, May 28, 1936.

37 Sioux City Tribune, September 14, 1932.

38 Unionist and Public Forum, September 14, 1939 (reprint from 1932).

39 Minutes of the Seventeenth Annual Convention, p. 68.

40 Ibid., p. 69.
} 
a national problem." $41 \mathrm{He}$ never wavered in his belief that the Holiday cause was "just and right." Institutions which stray from that which is human, he remarked, "must be brought back to human justice." Short affirmed his belief in the rights of property, but he also asserted that "men who have an immense amount of property do not have human rights that other men do not have." 42

While Wallace Short's papers covering the depression era are no longer extant and the Reno papers provide only scant correspondence between the Unionist editor and the Holiday president, there is still sufficient evidence to demonstrate the existence of a solid relationship between the two men. Short praised Reno's role as a farm leader even during his years (1924-27) as editor of the Union Advocate. $\mathrm{He}$ continued to push Reno's cost-of-production scheme and other agricultural panaceas through the Unionist and Public Forum which he established in May 1927. The association grew and perhaps reached its apex during the Holiday turbulence of 1932 and 1933. Reno and Short often appeared on the same platform, not only in Sioux City but throughout Iowa and eastern South Dakota. "For 20 years," Short wrote at the time of Reno's death, "I have known Milo Reno. I spoke many times from the same platform with him."43

Reno's courage and humanity were consistently praised by Short. "He alone stuck to his guns," Short wrote, concerning Reno's fortitude during the Holiday strike of $1932 .{ }^{44} \mathrm{He}$ recalled the time they were together at a Sioux City cafe on Fifth and Douglas, when Reno surprised him by suddenly ordering 200 sandwiches. When asked what he wanted with so many sandwiches, Reno replied: "There are 100 pickets out by the Sioux City bridge who have nothing to eat." 45 The two men also worked closely together following the assault on Judge Bradley in his Le Mars courtroom in April 1933, and other violent disturbances in Plymouth and Crawford counties. Governor Herring, like his predecessor, called out the militia and in a speech at lowa City suggested that the leaders in the violence were not farmers. The implication was that communists were involved in setting off the disturbances. This brought an angry retort from Short, who in a Unionist and Public Forum article on May 18, 1933, demanded verification of the charges. Reno joined the controversy, asking the governor "if you have furnished Mr. Short

41 lowa Union Farmer, September 7, 1932.

42 Minutes of the Seventeenth Annual Convention, p. 59.

43 Iowa Union Farmer, May 28, 1936.

44 Ibid.

45 Ibid. 
with the information he has asked for, and if you have not, why not, and if you cannot, why not retract the statement?" 46

Short was convinced that the death of Reno in the spring of 1936 "marked a major crisis in American history," 47 and he was later designated as one of the members of a committee to investigate the possible publication of a memorial volume in honor of the Holiday president. ${ }^{48}$ The book was written by Roland White.

The Holiday Association and Milo Reno often expressed their appreciation of the fiery editor's support. A Holiday meeting at Boone in May 1933 saw several hundred participants give Short a standing vote of thanks for "his great help in the past and in the future." 49 Short often addressed Farm Holiday and Farmers' Union conventions at all levels, and at the seventeenth Farmers' Union State Convention in Des Moines, September 17-23, 1933, he was introduced by President Glen Miller as one of the "greatest statesmen" in Iowa and as one who "has been weighed in the balance many times and has never been found wanting." 50 When Reno was having financial difficulties and it appeared the Farm Holiday News might have to cease publication during the summer of 1933, he turned to Short as a possible resource. Although Short's assistance did not prove necessary, Reno wrote a friend that "we can make an arrangement with $\mathrm{Mr}$. Short that will enable us to continue, at least for the coming year."51 Reno also thanked the Unionist editor for his long-standing assistance, noting the "splendid cooperation I have always had from you personally, and assuring you that the Holiday Association and the Farmers' Union feel the obligation to you as sincerely as I do myself." 52 When Max Hueschen, editor of the Holstein Advance, criticized Short's effort to win the governorship as the candidate of the Farmer-Labor party because he was too closely associated with Reno, Short shot back with a spirited defense, responding that Reno had been "right oftener than any public figure in Iowa." 53 Reno, obviously gratified at Short's defense, noted that "those acquainted with Wallace M. Short would expect

46 Reno to Clyde Herring, May 23, 1933, Reno Papers, Special Collections, The University of Iowa Libraries, Iowa City.

47 lowa Union Farmer, May 28, 1936.

48 Page Hawthorne to Wallace Short, November 20, 1940, Reno Papers. White's memorial volume is cited above, fn. 16 .

49 Farm Holiday News, May 1933.

50 Minutes of the Seventeenth Annual Convention, p. 50.

51 Reno to Emil Lorkiss, July 11, 1933, Reno Papers.

52 Reno to Wallace Short, July 2, 1933, Reno Papers.

53 Iowa Union Farmer, August 15, 1934. 
nothing less." 54 On the other hand, there were those who, like W. C. Daniel, while noting Short's contribution, felt "he tried to push himself ahead a little." 55

Throughout the depression-ridden years of the 1930s, Short and Reno shared a common ideology. Short supported Reno's cost-ofproduction program, the Frazier-Lemke refinancing bill, the withholding actions of 1932 and 1933, and inflationary measures. Their struggles on behalf of the impoverished farmers, however, led them to approve reactionary movements like the "Modern 76ers," who sought to curb the evils of corporate capitalism and combat political and economic corruption not only with ballots but with force, should that prove necessary. ${ }^{56}$

The Modern 76ers appear to have been imported to Iowa from Connecticut by a rapid-fire orator, inventor, and political agitator, Lester Barlow. Short had met Barlow as far back as 1920 and had known him in 1924 when both were working for the election of Robert M. La Follette. Like Short, Barlow appears to have lost faith in both major parties, although in 1932 he came to Iowa for the purpose of campaigning for the election of Franklin Roosevelt (but not the Democratic party). ${ }^{57}$ Short, captivated by Barlow's fiery populist oratory, recommended him for speaking engagements. ${ }^{58}$

Early in 1933, Reno wrote a correspondent that Short was speaking in the interest of the Modern 76ers. This organization, Reno noted, "while not an auxiliary of the Holiday Association, is at least a movement in the right direction." 59 Short had vigorously championed the cause of the 76ers since the fall of 1932 , convinced that the purpose of the movement was "to organize the good citizenship of America, to clean up graft and corruption, and make our institutions function as they were intended. ... We have not heard anyone proposing a better way and we had better do something and do it now."60 The Modern 76ers were strong in O'Brien County, where their president was Simon Tjossem, a God-fearing, pious Quaker and a close friend of Wallace Short. Tjossem was one of the farmers convicted of conspiracy and contempt of court following the violence in Plymouth County in April 1933, and was given a

54 Ibid.

55 W. C. Daniel, tape recording, John Shover Collection.

56 Shover, Cornbelt Rebellion, pp. 59-65.

57 Lester Barlow, tape recording, John Shover Collection.

58 W. C. Daniel, tape recording, John Shover Collection.

59 Reno to W. L. Achenbach. March 1, 1933, Reno Papers.

60 Short, tape recording, John Shover Collection, quoting Unionist and Public Forum, October 27, 1932. 
one-year suspended sentence. ${ }^{61}$ Efforts were made to link the Modern 76ers (including Barlow, Reno, and Short) to the Communist party by the American Vigilante Federation and its honorary general manager, Dr. Harry Jung. ${ }^{62}$ This same organization attacked the ACLU for helping finance the legal defense of the 76ers, calling it "the intellectual outpost of all radical, revolutionary groups in the U.S." 63

Short's vision of a just society, however, was larger than Reno's, and his support of the 76ers (whose strength was minimal) and the Union party of 1936 were aberrations stemming from the feeling that the law no longer provided justice, and that the established order had failed to act vigorously on behalf of the common people. He believed that the Holiday movement was a harbinger of change. "These militant farmers," he told Arthur Holt, "are out to get a social order in which people who do such necessary work as farming will not work for nothing, but will have a just share in the rewards of society. These boys believe in a real and new direction."64 $\mathrm{He}$ was, of course, temporarily misled by the demagoguery of Huey Long and Charles Coughlin-and he soon repudiated the priest. $\mathrm{He}$ never lost faith, however, in William Lemke, and his strong belief in the necessity of an adequate old-age pension plan made him a supporter of Dr. Francis E. Townsend. He remained an admirer of Huey Long, who had come up "from the cotton patch" to battle "at the crossroads." Nor did he find fault with the 76ers-he simply ceased to mention them even in later years when he fondly recalled the farmers' stand during the Holiday strike.

During his career, Short championed successive progressive crusades from Theodore Roosevelt's bolt from the Republican party in 1912 through Henry Wallace's presidential campaign in 1948. He consistently defended civil rights for all-the IWWs during the World War I era, communists and socialists during the 1930s when he attacked the excesses of the Dies Committee (later the HUAC), and equality for Black Americans during the 1940s. Short was an opponent of Iowa's criminal syndicalism law, which he viewed as a powerful threat to civil liberties and which made the state motto, "Our Liberties We Prize and Our Rights We Will Maintain," a gross hypocrisy. He joined the Iowa Civil Liberties Union in 1935, at a time

61 O'Brien County Bell, June 28, 1933, clipping in John Shover Collection.

62 Shover, Cornbelt Rebellion, p. 124.

63 O'Brien County Bell, June 28, 1933, clipping in John Shover Collection.

64 Quoted in Arthur E. Holt, "On the Trail of the Iowa Protesters," Christian Century (May 17, 1933), p. 652. 
when he feared there were growing threats to "the academic freedom of Iowa teachers." $65 \mathrm{He}$ was a committed proponent of collective bargaining a generation before the passage of the Wagner Act. As an octogenarian, but a still-active editor during the early postwar years, he warned of the dangers of nuclear proliferation. He urged world brotherhood and peaceful relations with the Soviet Union. To the end of his life, he sought the unity of all "who weary of poverty in the midst of plenty." 66 Only now the cause was global.

65 Unionist and Public Forum, March 28, 1935.

66 Ibid., August 27, 1936. 